\title{
Apresentação
}

\section{Rosângela Gabriel}

Universidade de Santa Cruz do Sul - UNISC - Rio Grande do Sul - Brasil

"(Per)cursos (inter)disciplinares em Letras" foi o tema que congregou quatro eventos promovidos pela Universidade de Santa Cruz do Sul e pelo GT Linguística e Cognição da Associação Nacional de Pós-Graduação e Pesquisa em Letras e Linguística - Anpoll, no período de 21 a 25 de agosto de 2017: VIII Conferência Linguística e Cognição, VIII Colóquio Leitura e Cognição, II Simpósio Internacional Leitura, Literatura e Mídia e XVIII Semana Acadêmica de Letras.

O objetivo comum desses eventos foi contribuir para a reflexão conjunta e a articulação entre pesquisadores da área de Letras - Linguística e Literatura - e de suas interfaces, buscando mapear percursos traçados nas últimas décadas, assim como projetar novos caminhos para que a área continue contribuindo para o desenvolvimento educacional, científico e artístico. A programação dos eventos conjuntos incluiu palestras, mesas-redondas, simpósios e painéis temáticas, e pode ser acessada em http://www.unisc.br/site/coloquio2017/index.html.

Para que a memória das discussões realizadas ao longo desse período não se perca, os organizadores propuseram a produção de três publicações, voltadas a públicos e temáticas distintas: o número 75, volume 42, 2017 da revista Signo; o número 2, volume 5, 2017, da revista Rizoma' (ISSN 2318-406X); e um ebook, que conta com o apoio financeiro do CNPq, a ser publicado em 2018.

O presente número da revista Signo guarda estreita relação com as temáticas concernentes ao GT Linguística e Cognição, que estão expressas na justificativa para a criação dessa comunidade epistêmica no contexto da ANPOLL: "a reflexão sistemática e regular da teorização linguística em torno da problemática cognitiva, presente de forma cada vez mais incisiva e promissora na agenda dos estudos sobre a linguagem, bem como na agenda das ciências da cognição, ${ }^{, i i}$. Nesse espírito, os artigos publicados nesta edição problematizam a embodied cognition, o estatuto cognitivo das metáforas, o processamento neural em bilíngues, a iconicidade, os dêiticos, a construção de dicionários a partir da semântica de frames, as representações mentais expressas na língua, dentre outros que podem ser conferidos no sumário desta edição.

Convidamos os leitores a pensarem conosco! Ótima leitura a todos!

\footnotetext{
i Disponível em https://online.unisc.br/seer/index.php/rizoma/index Acesso em 05/12/2017.
}

ii Disponível em http://anpoll.org.br/gt/linguistica-e-cognicao/ Acesso em 05/12/2017. 